\title{
Comparison of the reproductive performance of the Kacang goats on three synchronization methods
}

\author{
Yendraliza *, Rahmi Febriyanti, Muhammad Rodiallah \\ Faculty of Agriculture and Animal Science, Universitas Islam Negeri Sultan Syarif Kasim Riau, Pekanbaru, \\ 28293 \\ *Correspondence: yendraliza@uin-suska.ac.id
}

Received: June 17th 2020 ; Accepted: October 16 ${ }^{\text {th }}, 2020$; Published online: November $26^{\text {th }}, 2020$

\section{Abstrak}

Tujuan: Penelitian ini bertujuan untuk mengetahui metode sinkronisasi yang tepat untuk menghasilkan kecepatan estrus, persentase estrus, persentase kebuntingan, persentase kelahiran pada kambing Kacang.

Metode: Penelitian ini menggunakan 45 ekor induk kambing Kacang yang telah melahirkan yang dibagi dalam 3 kelompok ( $n=15)$. Kelompok pertama di injeksi dengan $1 \mathrm{ml} \mathrm{PGF} 2 \alpha$ (Lutalyse ${ }^{\mathrm{TM}}$ ) pada

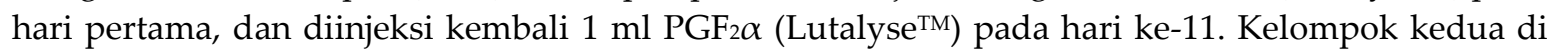
injeksi dengan $1 \mathrm{ml}$ of $\mathrm{GnRH}$ (Fertagyl ${ }^{\mathrm{TM}}$ ), dan diikuti injeksi $1 \mathrm{ml} \mathrm{PGF} 2 \alpha$ (Lutalyse $^{\mathrm{TM}}$ ) pada hari ke7. Kelompok ketiga di injeksi $1 \mathrm{ml}$ progesterone (Progesterone-C) dan diikuti dengan injeksi $1 \mathrm{ml}$ $\mathrm{PGF}_{2} \alpha$ (Lutalyse ${ }^{\mathrm{TM}}$ ) pada harike-7. Pengamatan estrus dilakukan pada hari ke-12 untuk kelompok pertama, hari ke-8 untuk kelompok kedua dan hari ke-8 untuk kelompok ketiga. Ternak yang estrus dikawinkan dengan pejantan yang telah disiapkan. Data dianalisa dengan uji $t$.

Hasil: Hasil penelitian menunjukkan bahwa metode sinkronisasi dengan pemberian $\mathrm{PGF}_{2} \alpha$ ganda dan kombinasi GnRH dan $\mathrm{PGF}_{2} \alpha$ pada kambing yang telah melahirkan menghasilkan visualisasi estrus yang bagus, estrus 100\%, kecepatan munculnya estrus 51.6 jam- 52.6 jam, persentase kebuntingan 100\%, persentase kelahiran 100\% dibandingkan dengan metode Progesteron dan $\mathrm{PGF}_{2} \alpha$. tetapi lama estrus, kelahiran kembar dan jumlah anak dalam kelahiran tidak berbeda nyata pada tiga metode sinkronisasi.

Kesimpulan: Metode kombinasi GnRH dan $\mathrm{PGF}_{2} \alpha$ dengan $\mathrm{PGF}_{2} \alpha$ ganda menghasil respon estrus yang baik, kebuntingan serta kelahiran yang optimal pada kambing yang pernah melahirkan dibandingkan kombinasi Progesteron dengan $\mathrm{PGF}_{2} \alpha$.

Kata Kunci: Kebuntingan; Kelahiran; Respon Estrus

\section{Abstract}

Objective: This study was conducted to investigate the effect of different methods synchronized on the reproductive performance of the Kacang Goats, estrus response, pregnancy rate, kidding rate, twins and litter size.

Methods: Forty-five dam of Kacang goats were divided into three groups $(n=15) ; 1)$ goats were injected $1 \mathrm{ml} \mathrm{PGF} 2 \alpha$ (Lutalyse ${ }^{\mathrm{TM}}$ ) on day 1st and after days 11nd. 2) goats have injected $1 \mathrm{ml}$ of $\mathrm{GnRH}$ $\left(\right.$ Fertagyl ${ }^{\mathrm{TM}}$ ) on day 1 st and the 7 th day was injected $1 \mathrm{ml}$ of $\mathrm{PGF}_{2} \alpha .3$ ) goats have received $1 \mathrm{ml}$ progesterone (Progesterone-C) on the first day and the 7 th day was injected with $1 \mathrm{ml} \mathrm{PGF} 2 \alpha$. Estrus observations were made on the 12th day for the first group, 8th day for the second group and 8th day 
for the third group. This data analyzed with a t-test. The effects were considered to be significant when the level of probability was less than $5 \%$.

Results: The results showed that visualization estrus (goods), the percentage of estrus $(100 \%)$, the onset of estrus (51.6 h- $52.6 \mathrm{~h}$ ), the percentage of pregnancy (100\%), birth percentage of kids $(100 \%)$ Kacang goats better on the use of double $\mathrm{PGF}_{2} \alpha$ and a combination of $\mathrm{GnRH}$ and $\mathrm{PGF}_{2} \alpha$ than the use combination progesterone with $\mathrm{PGF}_{2} \alpha$ but the duration of estrus, twins and the kidding rate no difference between treatments.

Conclusions: Synchronization method using a combination of $\mathrm{GnRH}$ with $\mathrm{PGF}_{2} \alpha$ and double $\mathrm{PGF}_{2} \alpha$ produces estrus responses, pregnancy rate and birth rates that are higher than the combination Progesterone with $\mathrm{PGF}_{2} \alpha$ synchronization method.

Keywords: Estrus Response; Kidding Rate; The Pregnancy Rate

\section{INTRODUCTION}

Indonesia's Goat population in 2018 reached $18,721,000$ heads with a growth rate of about only $1.30 \%$, while Riau Province only had 210,987 heads in 2018 with a growth rate of $6 \%$ [1]. The same source stated that the low growth rate of the goat population was probably due to the high rate of goat slaughter (1.889 million head) in Indonesia.

Kacang Goat is a native goat that is spread throughout Indonesia, maintained in rural areas with extensive maintenance systems. Kacang goats are agile, resistant to various weather conditions, and can adapt quickly in new environments [2]. Kacang goats are important to develop because goat meat is considered premium and it's associated with higher prices. Also, goats can convert plants and household products and residues into the meat, fiber, skin, and milk [3]. The growth rate of Kacang goat in Indonesia does not increase because the maintenance system is still semi-intensive [4].

Increasing the population of Kacang goats can be done by carrying out artificial insemination. The success of artificial insemination is influenced by the quality of estrus. Estrus synchronization is a technique of manipulating the estrous cycle to cause the symptoms of estrus in a group of livestock simultaneously. Synchronization can be done with hormone therapy [5]. Several reports of researchers have used $\mathrm{PGF}_{2} \alpha$ in local goats, at a dose of $4 \mathrm{mg} /$ head, 2 injections with an interval of 11 days intramuscularly [6], progesterone in Italian goats [7], CIDR on Malaysian local goats [8]. Combination of GF2 $\alpha$ and
GnRH in Kacang Goats [9]. The performance of synchronization, management, and environment are affected by livestock conditions [10]. Investigation of the appearance of Kacang goat reproduction in Payakumbuh by comparing various synchronization hormones has never been done.

The purpose of this study was to look at the percentage birth of Kacang goats; estrous response, pregnancy percentage and the births percentage of Kacang goats with different types of synchronizing hormones.

\section{MATERIALS AND METHODS}

\section{Materials}

The study used 45 dams of Kacang goats which were divided into 3 groups based on body weights (17-31 kg) and nonpregnant dams of Kacang goats (each group consisted of fifteen replication). The materials and tools used in this study were the GnRH (Fertagyl ${ }^{\mathrm{TM}}$, Gonaderolin), $\mathrm{PGF}_{2 \alpha}$ (Lutalyse $^{\mathrm{TM}}$ as, Dinoprost Trometamol 5 $\mathrm{mg} / \mathrm{ml}$ ), Progesterone (Progesterone-C, Medroxyprogesterone acetate 6.5mg), syringes and cotton.

\section{Research procedures}

Forty-five dam of Kacang goats were divided into three groups $(n=15)$ treatments. The first treatment was an injection of $1 \mathrm{ml}$ PGF2 $\alpha$ intramuscular on the first day and was repeated on the 11th day in the same manner (Figure 1a). The second treatment was an injection of $1 \mathrm{ml} \mathrm{GnRH}$ on the first day and the 7 th day, was injected $1 \mathrm{ml}$ of PGF2 $\alpha$ (Figure $1 b)$ an intramuscular and the third treatment 
injected an intramuscular of $1 \mathrm{ml}$ of progesterone on the first day and the 7th day was injected $1 \mathrm{ml}$ PGF2 $\alpha$ (Figure 1c). The estrus has detected three times a day; at 08.0009.00 am, 12.00-13.00, and 4.00-5.00 pm for 4 days. The percentage of being pregnant was evaluated from twice the estrous cycles after the dam is mated. The duration of estrus was carried out for 1 hour visually and assisted with the male effect since the second hormone was injected.

\section{Scoring estrus visualization}

The visualization score of the estrus was characterized by changes in the color of the vulva, vulva swelling and mucus on the vulva; a) Discoloration of the vaginal mucosa to redness: is given a score of 3 for red, score 2 for pink and score 1 for pale pink. b) The occurrence of swelling of the vulva is given a score of 3 if it experiences swelling, a score of 2 if the vulva has only slight swelling and a score of 1 if the vulva is wrinkled. c) Mucus discharge from the vulva viscosity of mucus estrus is given a score of 3 if the mucus is viscous, clear hanging or soaking around the vulva, score 2 if the amount is small and score 1 if there is no mucus. The average value of the estrus is obtained from the sum of the estrus score in the observation period and divided by the number of observations.

The percentage of estrus is the total number of goats that estrus after the last hormone injection is divided by the number of animals injected in the group (\%). The onset of estrus is the time it takes from the last hormone injection until the emergence of estrus is marked by a score of 1 (hours). The duration of the estrus is calculated from the appearance of the estrus to the disappearance of the estrus sign (hours). The percentage of pregnancy is measured from the total number of pregnant females divided by all the females that have been mated in the group (\%). The birth percentage of kids is measured by the total number of kids at birth divided by the total number of pregnant females in the group.
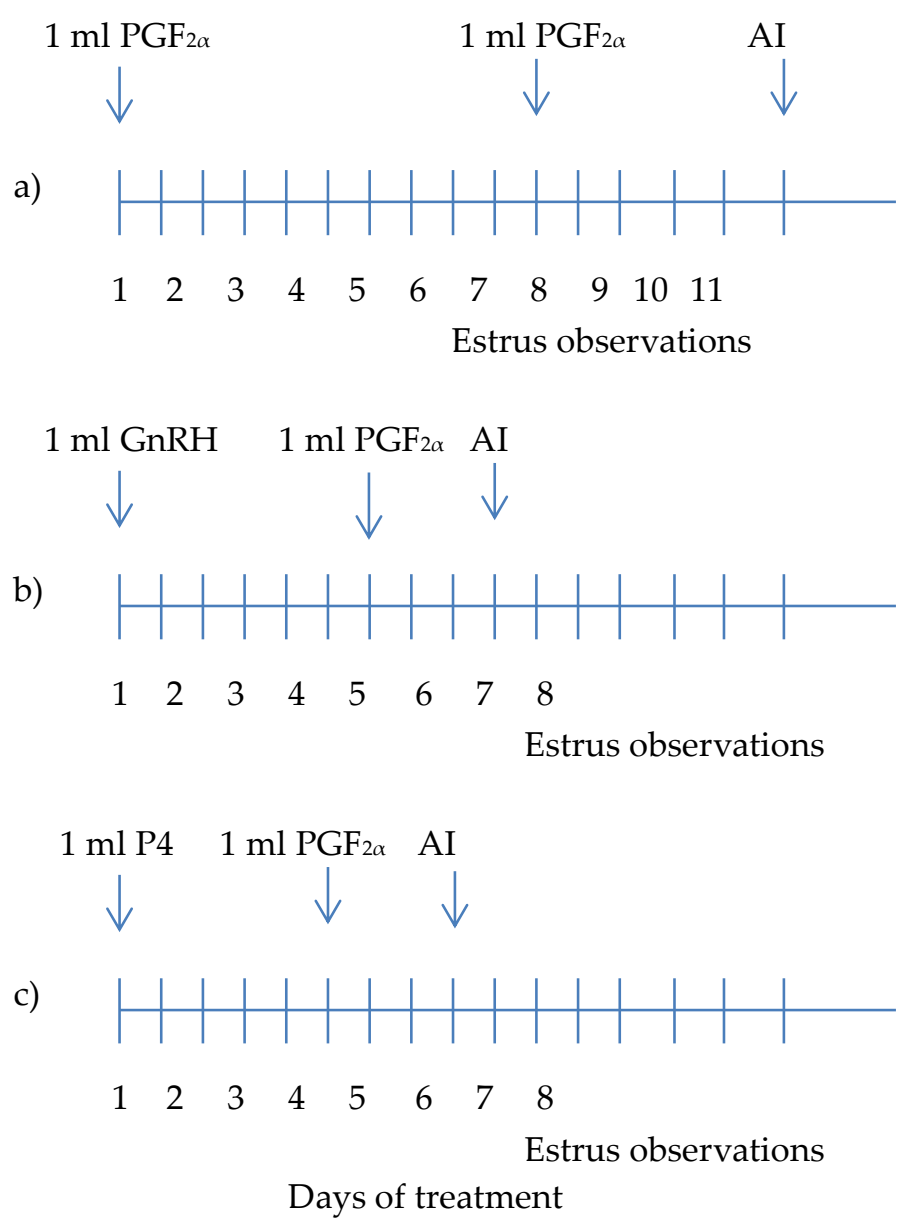

Figure 1. Schedule of treatments a) double $\left.\mathrm{PGF}_{2 \alpha} ; \mathrm{b}\right) \mathrm{GnRH}+\mathrm{PGF}_{2 \alpha} ; \mathrm{c}$ ) Progesterone $+\mathrm{PGF}_{2 \alpha}$ 
(\%). The kidding rate; The number of kidded females/number of treated females $\times 100$.

\section{Analysis of data}

The obtained data were subjected to repeated measures descriptive. This data analyzed with a t-test. The effects were considered to be significant when the level of probability was less than $5 \%$.

\section{RESULTS AND DISCUSSION}

\section{Visualization of estrus}

The use of different synchronization hormones on Kacang goats in Payakumbuh results in a different visualization of estrus (Figure 2). Vulva discoloration, swelling of the vulva, Kacang goats mucus secretions better on the use of double $\mathrm{PGF}_{2} \alpha$ with a combination of GnRH and $\mathrm{PGF}_{2} \alpha$ than the use of $\mathrm{PGF}_{2} \alpha$ singles.

The percentage of estrus, onset of estrus, duration of estrus, percentage of pregnancy and the percentage of birth Kacang goats

Three types of synchronization methods have a significant effect on the percentage of estrus, onset of estrus, percentage of pregnancy and the percentage of birth of Kacang goats, but the duration of estrus is not significantly different among synchronization methods (Figure 3).

\section{Percentage of estrus}

The percentage of estrus of Kacang goats synchronized with different methods resulted in a different percentage of estrus. This can be seen from the visualization of estrus in each treatment method is also different.

\section{Onset estrus}

The use of PGF $2 \alpha$ with two injections obtained the fastest onset of 51 hours 6 minutes. Followed by the use of a combination of $\mathrm{GnRH}$ and $\mathrm{PGF}_{2} \alpha, 52$ hours 2 minutes. The use of one injection of $\mathrm{PGF}_{2} \alpha$ only results in the onset of estrus 63 hours 4 minutes.

\section{The duration of estrus}

The duration of the estrus of Kacang goats in this study did not differ between the use of the synchronization hormone types (21.4h - $22.2 \mathrm{~h}$ ).

\section{The percentage of pregnancy}

The pregnancy percentage of Kacang goat in this study was higher in the use of double synchronization hormones $\mathrm{PGF}_{2} \alpha$ and combination of the hormones GnRH and $\mathrm{PGF}_{2} \alpha \quad(100 \%)$ compared to the use of progesterone and $\mathrm{PGF}_{2} \alpha(80 \%)$.

\section{The percentage of birth}

The percentage of birth of kid Kacang goat is significantly different. The use of the $\mathrm{PGF}_{2} \alpha$ double hormones and the combination of GnRH and $\mathrm{PGF}_{2} \alpha(100 \%)$ is higher than the use of the combination hormones progesterone and $\mathrm{PGF}_{2} \alpha(80 \%)$.

\section{The kidding rate and twins}

The double $\mathrm{PGF}_{2} \alpha$ synchronization hormones and the combination of GnRH + $\mathrm{PGF}_{2} \alpha$ results in a higher number of twins ( $\mathrm{n}$,

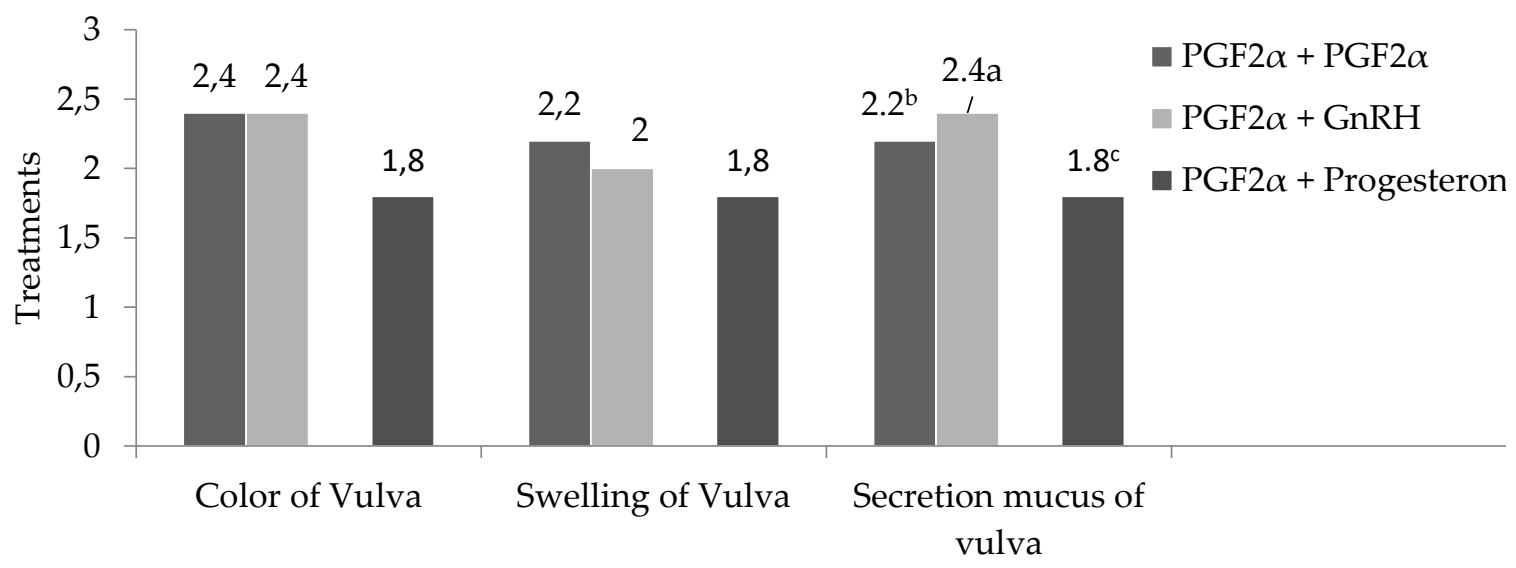

Figure 2. The estrus intensity averages of the Kacang goats on the farm of Payakumbuh 
12 head) and the total of a birth higher number of lamb ( $\mathrm{n}, 21$ head) compared to the combination of hormone progesterone + $\mathrm{PGF}_{2} \alpha$ (n, 6 head and 15 head) (Table 1). The total kidding rate obtained in the Kacang goat in this study did not differ between the use of the double $\mathrm{PGF}_{2} \alpha$ hormone, the GnRH + $\mathrm{PGF}_{2} \alpha$ combination and the progesterone + $\mathrm{PGF}_{2} \alpha$ combination.

Visualization of different estrus between treatments is caused by different conditions of livestock, feed and livestock environment. Muayad et al [8] state that livestock types and environmental conditions affect the visualization of estrus occurring in goats. Hafez \& Hafez [11] explained that the onset of symptoms of vulvar swelling and redness depends on the amount of estrogen produced by mature follicles, besides, the influence of estrogen causes the development of epithelial cells with the onset of hyperplasia and hypertrophy. This will increase the sensitivity of the female genital organs marked by changes in the vulva and transparent mucus [12]. The results of the vulva color in this study differed from the study Almadaly et al [13] that the visualization of estrus intensity of Rahmani Egyptian sheep differed in the administration of progesterone and $\mathrm{PGF}_{2} \alpha$. This difference in visualization is probably caused by different types of livestock, breed [14]. Furthermore, Jainudeen and Hafez [15], states that at the onset of estrus, goats exhibit symptoms of behavioral change, the vulva is swollen, reddened, and wet and often wags its head.

The low percentage of estrus in the third treatment is probably due to not all goats have corpus luteum so that $\mathrm{PGF}_{2} \alpha$ is not effective at work [16]. The corpus luteum's resistance to $\mathrm{PGF}_{2} \alpha$ is caused by the interaction of paracrine and autocrine between $\mathrm{PGF}_{2} \alpha$, oxytocin, and progesterone [17]. Besides, this is also caused the existence of the hormone progesterone in controlling the secretion of luteinizing hormone from the anterior pituitary caused that $\mathrm{PGF}_{2} \alpha$ performance is not effective in lysis of the corpus luteum [18]. Moreover, the percentage of estrus goat in this study is higher than the percentage of goat estrus in Malaysia (90\%) using CIDR [8], the percentage of buffalo estrus using a combination of GnRH and $\mathrm{PGF}_{2} \alpha(91.2 \%)$ [19], the percentage of estrus of Nigerian goats (41.6 \%- $91.6 \%$ ) [20], and the estrus percentage of Bali cattle $(70 \%)$ [21]. The differences variations in the

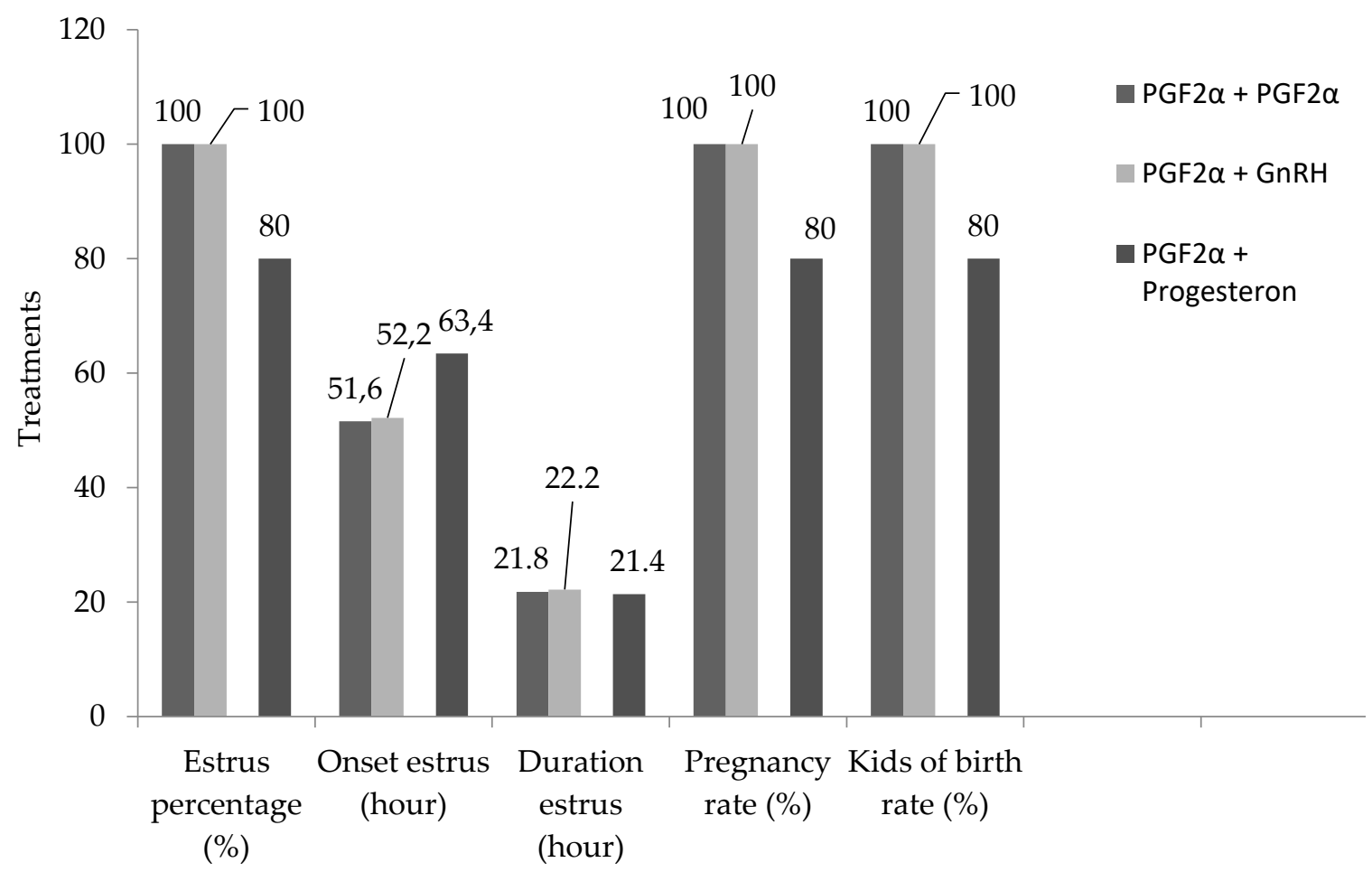

Figure 3. The percentage of estrus, the onset of estrus, duration of estrus, pregnancy rate and kids of the birth rate of Kacang Goats in Payakumbuh 
percentage of estrus are caused by hormones, ages of livestock and types of livestock as well as the maintenance system and environments that are used differently [3].

The difference onset of estrus in Kacang Goat's is due to the physiological conditions of livestock and the types of synchronic hormones used are not the same. Wave patterns in follicular dynamics in each goat are different. These different patterns produce different estrogen hormones, resulting in a different estrus onset [16]. The onset of estrus results in this study is still in the normal range of 24-72 hours [22]. The results of other studies indicate that the onset of estrus of Kacang goats in this study $(51.6 \mathrm{~h}-63.4 \mathrm{~h})$ higher than the onset of estrus of Kacang goats in Aceh synchronized with $\mathrm{PGF}_{2} \alpha$ (38 \pm 2.39 hours) [9], the onset of sheep estrus synchronized with $\mathrm{PGF}_{2} \alpha$ and progesterone is 48 hours [23] and onset estrus of goats in Nigeria ( $37.4 \mathrm{~h}-39.1$ h) [20]. The diversity of estrus onset in each ruminant animal is strongly influenced by ovarian activity, especially the presence of an active corpus luteum and whether or not the reproductive cycle is normal [16]. Also, the dose of the hormone used affects the performance of the hormone itself in giving reaction to the livestock body [24].

The duration of estrus these results are in the normal ranges, $24 \mathrm{~h}-48 \mathrm{~h}$ [25]. The duration of estrus obtained from the results of this study is shorter than reported by Omontese et al [20] the red Sokoto Goats use the eCG hormone $(22-39 \mathrm{~h}$ ) and the duration of estrus of Kacang goats in Aceh $(40.40 \mathrm{~h}$ ) reported by Syafruddin et al [9] which is synchronized with $\mathrm{PGF}_{2} \alpha$. The difference duration of estrus in studies of some goats is caused by the types of goats, the types of hormones used and the management of maintenance and feed used differently [10]. Furthermore, Omontese et al [26] stated that the successful synchronization of goats in Nigeria was influenced by good feed management by breeders. Gordon [18] states that one that affects the duration of estrus is feed because nutrient deficiencies will result in the low secretion of estradiol and will affect the proliferation of tissues making up the uterine endometrial lining.

The difference percentage of pregnancy in Kacang Goat's is due to differences in estrus intensity. Whitley and Jackson [24] state that the signs of estrus will affect the success of pregnancy. This statement is reinforced by Naderipour et al [27] that clear signs of estrus will produce high pregnancy. The percentage of pregnancy of Kacang goats in this study is in line with the percentage of pregnancy of Goat Rahmani Egyptian [13] that different hormones used in synchronization produce different percentages of pregnancy. The percentage of pregnancy Kacang goats in this study is different from the percentage of pregnancy goats of Brazil which use a combination of the hormones CIDR and $\mathrm{PGF}_{2} \alpha$ in different BCS (36\%-87\%) [7] and the percentage of goat pregnancy in Iran using a different type of synchronization hormones (53\%- $84 \%$ ) [17]. This difference in pregnancy percentage is influenced by breed, nutrition and maintenance management to produce a different estrus response [16].

The difference percentage of birth in Kacang goats is caused by differences in estrus responses and differences in pregnancy rates for Kacang goats. This statement is in line with Silva et al [7] and Hashemi and Safdarian [17] which found different types of hormones used in synchronization produced different pregnancy and births. This difference in birth rate is closely related to female performance reproduction, nutrition and management carried out. Good nutrition and fulfilled for pregnant animals will produce a good birth [25].

The difference of twins born in Kacang goats is because the mating system, maintenance management and type of

Table 1. The kidding rate and the total twins Kacang goats

\begin{tabular}{|c|c|c|c|c|c|}
\hline \multirow{2}{*}{ Treatments } & \multirow{2}{*}{$\mathrm{n}$} & \multicolumn{2}{|c|}{ Type of birth } & \multirow{2}{*}{$\begin{array}{l}\text { Total } \\
\text { (head) }\end{array}$} & \multirow{2}{*}{ Kidding rate } \\
\hline & & Single (head) & twins (head) & & \\
\hline Double $\mathrm{PGF}_{2} \alpha$ & $15 / 15$ & 9 & 12 & 21 & 1.40 \\
\hline $\mathrm{GnRH}+\mathrm{PGF}_{2} \alpha$ & $15 / 15$ & 9 & 12 & 21 & 1.40 \\
\hline Progesteron $+\mathrm{PGF}_{2} \alpha$ & $14 / 15$ & 9 & 6 & 15 & 1.07 \\
\hline
\end{tabular}


livestock used are the same. This is because the hormones estrogen and gonadotropins trigger the birth of twins [17]. The use of different hormones in this study did not add to the type of multiple births in Kacang goats. Twin births in this study are different from goats in Iran (0.62) [17]. Muayad et al [8] state that the birth of twins is not determined by the synchronization method used. These results are in line with Abecia et al [16] that the birth of twins in goats is determined by breeds and genetics.

In the end, the number of kids birth in this study also differed in the use of different hormones. The difference in the number of kids birth is due to differences in pregnancy rates in Kacang goats. Dohare et al [28] state that paritas, age, the body size of the parent and genetic parents influence the value of the kidding rate. the litter size of this research is lower when compared to goats in Italy (1.6 VS 1.4) [7] and the litter size of this research is higher when compared to goats in Iran (1.061.2 VS 1.07-1.4) [17]. This difference is due to differences in breeds, types of hormones used and different livestock environments.

\section{CONCLUSION}

Synchronization method using a combination of $\mathrm{GnRH}$ with $\mathrm{PGF}_{2} \alpha$ and double $\mathrm{PGF}_{2} \alpha$ results better in the reproductive performance of Kacang goats with $100 \%$ estrus response, $100 \%$ pregnancy rate, $100 \%$ kids of birth rate, and litter size 1.4 compared to the combined progesterone with $\mathrm{PGF}_{2} \alpha$ synchronization methods.

\section{CONFLICT INTEREST}

The authors declare there is no conflict interest in this research.

\section{ACKNOWLEDGEMENTS}

The authors give thanks to Universitas Islam Negeri Sultan Syarif Kasim Riau c.q Research Center University for financial support. The author thanks to Dinas Pertanian dan Peternakan Payakumbuh, specially to Riswanda.

\section{REFERENCES}

1. Directorate General of Livestock and Animal Health. 2017. Statistik Peternakan dan Kesehatan Hewan 2017. Directorate General of Livestock and Animal Health, Ministry of Agriculture, Jakarta

2. Sulaksono, A., S. Suharyati, and P. E. Santosa. 2010. Penampilan Reproduksi (Service Per Conception, Lama Kebuntingan Dan Selang Beranak) Kambing Boerawa Di Kecamatan Gedong Tataan Dan Kecamatan Gisting. J. Pharm. Sci. 2(2): 145-165. https://doi.org/10.1186/ 1475-2875-12-4

3. Dubeuf, J. P. 2011. The social and environmental challenges faced by goat and small livestock local activities: Present contribution of research-development and stakes for the future. Small Rumin. Res. 98(1-3): 3-8. https://doi.org/10.1016/j.small rumres.2011.03.008

4. Syafruddin, T. N. Siregar, Herrialfian, T. Armansyah, A. Sayuti, and Roslizawaty. 2010. Efektivitas Pemberian Ekstrak Vesikula Seminalis Terhadap Persentase Berahi Dan Kebuntingan Pada Kambing Lokal. J. Kedokt. Hewan. 4(2):53-60.

5. Letelier, C. A., I. Contreras-Solis, R. A. García-Fernández, M. A. Sánchez, P. García-Palencia, B. Sánchez, and A. Gonzalez-Bulnes. 2011. Effects of oestrus induction with progestagens or prostaglandin analogues on ovarian and pituitary function in sheep. Anim. Reprod. Sci. 126(1-2): 61-69. https://doi.org/ 10.1016/j.anireprosci.2011.04.012

6. Wurlina. 2005. Pengaruh Berbagai Dosis Prostaglandin F2 terhadap Kualitas Birahi pada Kambing Lokal. Media Kedokt. Hewan. 21(2): 84-87.

7. Silva L. M., D. Rondina, A. A. Araújo, C. Sargentini, M.T. Lima, M. R. C. Rodrigues, and F. V. Rodrigues. 2011. Reproductive responses and progesterone levels of postpartum oestrus synchronization in goats with different body reserves and progesterone levels of postpartum oestrus synchronization in goats with different body reserves. Ital. J. Anim. Sci. 10(42): 160-164. https://doi.org/10.4081/ijas.2011. e42 
8. Muayad, T. M., M. Z. H. Haniza, and I. Husni. 2019. Reproductive performance of different goat breeds in Malaysia. Indian J. Anim. Res.53 (1): 24-27. https://doi. org/10.18805/ijar.v0iof.7002

9. Syafruddin, S., J. Melia, T. Armansyah, T. N. Siregar, S. R. H. Siregar, G. Riady, and Hamdan. 2016. Perbandingan Kinerja Berahi Kambing Kacang Dan Kambing Peranakan Etawah (PE) Yang Mengalami Induksi Berahi Dengan PGF2 ALFA. J. Med. Vet. 10(1): 55-58.

10. Hafez, E. S. E., and B. Hafez. 2016. Folliculogenesis, Egg Maturation, and Ovulation in Reproduction in Farm Animals. Lippincott Williams \& Wilkins. Baltimore, Maryland, USA. pp. 68-81. https://doi.org/10.1002/9781119265306.ch5

11. Hafez, E. S. E., and B. Hafez. 2016. Transport and Survival of Gametes in Reproduction in Farm Animals, Lippincott Williams \& Wilkins, Baltimore, Maryland, USA. pp. 82-95.

12. Satria, Y. E., T. L. Yusuf, and Amrozi. 2016. Determination Of Optimal Mating Time Based On Ovary Ultrasonography With Estrous Clinical Symptoms In Etawa Crossbreed Goat. J. Vet. 17(1): 64-70. https://doi.org/10.19087/jveteriner.2016.17. 1.64

13. Almadaly, E., M. Ashour, I. El-Kon, B. Heleil, and E.-S. Fattouh. 2016. Efficacy of various synchronization protocols on the estrus behavior, lambing rate and prolificacy in Rahmani Egyptian ewes during the non-breeding season. Asian J. Anim. Vet. Adv., 11(1): 34-43. https:// doi.org/10.3923/ajava.2016.34.43

14. Ramos A. F., and B. D. M. Silva. 2018. Hormonal Protocols in Small Ruminants in Reproduction Biotechnology in Farm Animals. pp. 2-18.

15. Jainudeen M. R., and E. S. E. Hafez. 2016. Cattle and Buffalo in Reproduction in Farm Animals. Lippincott Williams \& Wilkins Baltimore, Maryland, USA. pp. 157-171.

16. Abecia, J. A., F. Forcada, and A. GonzálezBulnes. 2012. Hormonal control of reproduction in small ruminants. Anim. Reprod. Sci. 130(3-4):173-179. https://doi. org/10.1016/j.anireprosci.2012.01.011
17. Hashemi, M. and M. Safdarian. 2017. The efficiency of different methods of estrus synchronization followed by fixed-time artificial insemination in Persian downy does. Anim. Reprod. 14(2): 413-417. https://doi.org/10.21451/1984-3143-ar825

18. Gordon, I. 2017. Reproductive technologies in farm animals.CABI.

19. Yendraliza, J. Handoko, and M. Rodiallah. 2019. Reproductive performance of buffalo-cows with various synchronization protocols in Kampar regency of Riau province. IOP Conference Series: Earth and Environmental Science. 260 (1):1-7. https:// doi.org/10.1088/1755-1315/260/1/012057

20. Omontese, B. O., P. I. Rekwot, H. J. Makun, I. U. Ate, J. S. Rwuaan, and M. U. Kawu. 2013. Oestrus induction using fluorogestone acetate sponges and equine chorionic gonadotrophin in Red Sokoto goats. South African J. Anim. Sci. 43(1): 6973. https://doi.org/10.4314/sajas.v43i1.8

21. Malik, A. Heppy, M. S. Djaya, and N. Widaningsih. 2018. Comparing Response of Estrus Synchronization in the Heifers and Cows on Estrus Initial, Duration of Estrus and Pregnancy Rate Bali Cattle. Adv. Anim. Vet. Sci. 6(6): 242-245.

22. Hafez, E. S. E., M. R. Jainudeen, and Y. Rosnina. 2016. Hormones, Growth Factors, and Reproduction in Reproduction in Farm Animals. Lippincott Williams \& Wilkins Baltimore, Maryland, USA. pp. 31-54.

23. Martinez-Ros, P., A. Gonzalez-Bulnes, E. Garcia-Rosello, A. Rios-Abellan, and S. Astiz. 2019. Effects of short-term intravaginal progestagen treatment on fertility and prolificacy after natural breeding in sheep at different reproductive seasons. J. Appl. Anim. Res. 47(1): 201-205. https://doi.org/10.1080/09712119.2019.1599 899

24. Whitley N. C., and D. J. Jackson. 2004. An update on estrus synchronization in goats: a minor species. J. Anim. Sci. 82: 270-276. https://doi.org/10.2527/2004.8213_supplE2 $70 \mathrm{x}$

25. Jainudeen, M. R., H. Wahid, and E. S. E. Hafez. 2016. Sheep and Goats in Reproduction in Farm Animals. Lippincott Williams \& Wilkins, Baltimore, Maryland, 
USA. pp. 172-181. https://doi.org/10.1002/ 9781119265306.ch12

26. Omontese, B. O., P. I. Rekwot, I. U. Ate, J. O. Ayo, M. U. Kawu, J. S. Rwuaan, and A. A. Bello. 2016. An update on oestrus synchronization of goats in Nigeria. Asian Pacific J. Reprod. January. https://doi.org/ 10.1016/j.apjr.2016.01.002

27. Naderipour, H., J. Yadi, A. G. K. Shad, and M. A. Sirjani. 2013. The effects of three methods of synchronization on estrus induction and hormonal profile in Kalkuhi ewes: A comparison study. African J. Biotechnol. 11(2): 530-533. https://doi.org/ 10.5897/ajb11.2718

28. Do hare, A. K., B. Singh, Y. Bangar, S. Prasad, D. Kumar, and G. Shakya. 2013. Influence of age, sex and season on morbidity and mortality pattern in goats under village conditions of Madhya Pradesh. Vet. World. 6(6): 329-331. https:// doi.org/10.5455/vetworld.2013.329-331 